XIV.

\title{
Berichte über Versammlungen, Kongresse, aus Instituten, Krankenanstalten usw.
}

Von der Tagung der Abteilung 19: „Allgemeine Pathologie und pathologische Anatomie" der 85. Versammlung Deutscher Naturforscher und Aerzte in Wien vom 22. bis 24. September 1913.

Zentralbl. f. allg. Pathol. u. pathol. Anat. 1913. Bd. 24. Nr. 21.

In den grossen Versammlungen hat das Interesse für die Geschwulstforschung unzwcifelhaft in letzter Zeit etwas nachgelassen. Es berubt das z. T. darauf, dass die Konferenzen für Krebsforsehung, die alle $3 \mathrm{~J}$ ahre stattfinden, den grössten Teil des vorliegenden Materials absorbieren. Allgemeine Geschwulstprobleme sind auch diesmal nicht verhandelt worden. Vielmehr beschränkten sich die wenigen Mitteilungen aus der Geschwulstlehre auf kasuistische Mitteilungen. So beobachtete Klemperer aus Brünn ein Ovarialsarkom bei einem jugendlichen Individuum. von Parsch (Wien) hat diffuse Geschwulstmetastasen in der Milz untersueht, die makroskopisch laaum hervortraten. Er hat 7 solche Fälle beobachtet. Die dazu gehörigen Primärtumoren sassen in den versehiedensten Organen. Fi oritschoner beschreibt ein Chorionepitheliom hei einer 61jährigen Frau, die zum letzten Male vor mehr als 20 Jahren eine normale Geburt durchgemacht hatte. Klunzinger (Wien) berichtet über einen merkwürdigen Fall von doppelter Geschwulstbildung in der Schilddrüse. In dem einen Lappen hatte sich ein Carcinom, in dem andern ein Sarkom entwickelt. Der einzige nicht kasuistische Vortrag aus der GeschwulstJehre war der von F. Winkler (Wien) gehaltene. Winkler hat zweierlei Versuche angestellt: Erstens hat er mit einem Pflanzenschleimpräparat, dem sogen. Peptin, Injektionsversuche in Lunge und Leber gemacht und hat dabei Zellwucherungen erzielt, die einem Neoplasma ähnlich sehen. Dann hat er Versuche mit dem sogen. Röntgenin-Merck gemacht. Röntgenin ist eine Substanz, die aus Serum von Tieren gewonnen wird, die längere Zeit mit Röntgenlicht bestrahlt wurden. Diese Substanz, in Geschwülste eingespritzt, erzeugt eine weitgehende Erweichung. Die Versuche wurden bei Carcinomen, Sarkomen und leukämischen Geschwülsten angestellt.

v. H. 